Research Article

\title{
Experimental Investigation of the Surface Temperature Distribution and Thermal Performance of an Intermittent Combustion Chinese Heated Wall
}

\author{
Shimeng Hao $\mathbb{D}^{1,2}$ Yuejia Xu $\mathbb{D}^{1},{ }^{3}$ Changming Yu $\mathbb{D}^{4},{ }^{4}$ Yehao Song, ${ }^{3}$ and Zhenghao Lin $\mathbb{D}^{3}$ \\ ${ }^{1}$ School of Architecture and Urban Planning, Beijing University of Civil Engineering and Architecture, No. 1, \\ Zhanlanguan Rd. Xicheng District, Beijing 100044, China \\ ${ }^{2}$ Beijing Advanced Innovation Center for Future Urban Design, Beijing University of Civil Engineering and Architecture, No. 1, \\ Zhanlanguan Rd. Xicheng District, Beijing 100044, China \\ ${ }^{3}$ School of Architecture, Tsinghua University, No. 1, Tsinghua Yuan, Haidian District, Beijing 100084, China \\ ${ }^{4}$ School of Landscape Architecture, Beijing Forestry University, No. 35, Tsinghua East Road, Haidian District, \\ Beijing 100083, China
}

Correspondence should be addressed to Yuejia Xu; xu-yj12@mails.tsinghua.edu.cn

Received 19 March 2018; Revised 31 May 2018; Accepted 22 July 2018; Published 25 September 2018

Academic Editor: Peter Majewski

Copyright (C) 2018 Shimeng Hao et al. This is an open access article distributed under the Creative Commons Attribution License, which permits unrestricted use, distribution, and reproduction in any medium, provided the original work is properly cited.

\begin{abstract}
Chinese heated walls represent a traditional space heating technique that is still widely used in vernacular houses in northern China. Such walls efficiently recover gas heat from heating stoves and reduce users' exposures to indoor air pollution. This experimental study proposed a heat recovery system composed of a heated wall and fireplace. Test rooms were set up to evaluate the surface temperature distribution and thermal performance of the heated wall in response to several combustion patterns. The results show that an intermittent combustion heated wall heated only by a stove used for cooking can produce a relatively more comfortable indoor environment without extra energy consumption. In this research, indoor air temperature was increased by 3.3 to $4.0^{\circ} \mathrm{C}$ over the control room. The temperature distribution of the heated wall's surface was nonuniform, with a temperature range of $116.03^{\circ} \mathrm{C}$. It was also found that the combustion pattern had a major impact on the initial and peak temperatures of the wall body's surface during combustion.
\end{abstract}

\section{Introduction}

In developing countries, exposure to high concentrations of indoor air pollution primarily comes from the combustion of traditional biomass fuels $[1,2]$. Over half of the world's population is exposed on a daily basis to harmful emissions that have adverse effects on the respiratory, cardiovascular, immune, and nervous systems [3-5]. In China, it is estimated that nearly $80 \%$ of all household fuel consumed is in the form of solid biomass or coal, while burning typically takes place in low-efficiency, traditional stoves $[1,3,6]$. Apart from the indoor air pollution, these traditional stoves or braziers produce additional problems including a low level of efficiency and poor performance with regard to space heating [6-8].
In the past, several traditional heat recovery systems have been developed, such as the Roman hypocaust [9, 10], Korean ondol [11-14], Chinese kang [15-20], and others. Some of these have been renovated and are still in use today. The Chinese heated wall is one such traditional heating system that is still in use in northern China (as shown in Figure 1). A typical heated wall is a hollowed brick wall connected to a coal stove. The wall body stores the heat from the hot gas and slowly releases it into the adjacent room. In central China, especially in areas with subhumid continental monsoon climates, people are less equipped to deal with cold winters. Beginning in 2011, we conducted long-term field measurements and investigations in the rural area of Chongqing Province in central China [21]. Existing rural houses frequently fail to achieve thermal comfort, especially 

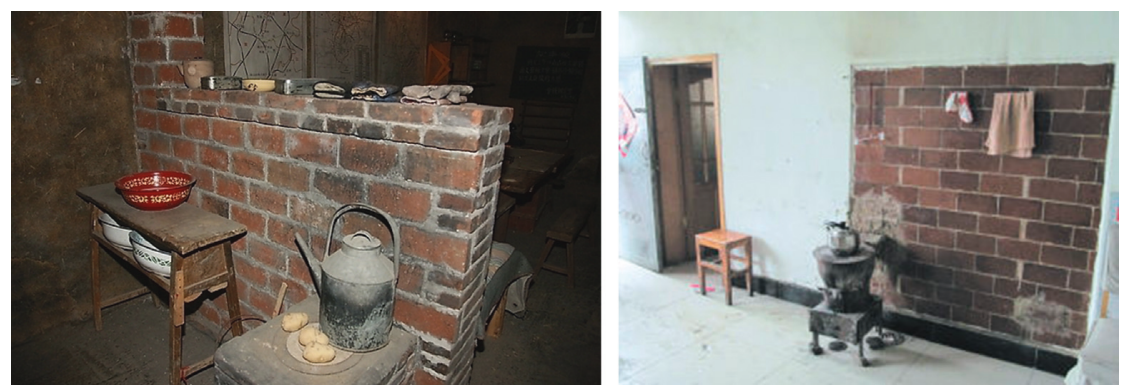

Figure 1: Traditional Chinese heated walls commonly used in northern China (photograph: left: http://www.huitu.com/photo/show/ 20121107/154758101200.html; right: http://news.163.com/14/1014/10/A8GSPI7D00014AED_mobile.html).

during wintertime. According to the field measurements performed in February of 2012, the average indoor air temperature was $2.45^{\circ} \mathrm{C}$, far below the thermal comfort zone. The heating season can stretch up to six months, from October to the following March.

We analyzed the impacts of cooking activities on indoor environmental quality and estimated the potential for heat recovery from cooking stoves that could be used for space heating. Fire pits and traditional cooking stoves are widely used in this area, directly discharging toxic gases indoors; they feature no heat recovery devices of any kind (as shown in Figure 2). The peak concentration value of PM2.5 while cooking in a traditional house was $48.055 \mathrm{mg} / \mathrm{m}^{3}$, and the peak value of CO concentration was $28.3 \mathrm{ppm}$. During the heating season, the average energy consumptions for wood and charcoal were $536 \mathrm{~kg}$ and $126 \mathrm{~kg}$ per household, respectively. We conducted indepth observations of occupants' behavior, including their cooking patterns and other activities. In this paper, a heat recovery system composed of a heated wall and fireplace was proposed for potential use in this rural area of central China, on the basis of precedent studies. The heated wall was connected to a stove used only for cooking which, unlike those used in northern China, recovered heat intermittently from cooking activities.

Several relevant precedent studies have been conducted that evaluated the thermal performance of heated walls $[22,23]$ and fireplaces [24]. Wang et al. established a dynamic heat transfer model for heated walls based on a theoretical analysis and lab testing [22]. These researchers determined that the heated wall's body released $45 \%$ of the total heat generated by fuel combustion into the surrounding room. The heat released by the indoor chimney provided an additional 25\%, and approximately $30 \%$ of the heat was released to the outdoors. The influence of the heated wall on indoor temperature was also simulated and measured. Zhang et al. applied PCM to the inner surface of a heated wall and simulated its thermal performance [23]. It was found that the indoor temperature fluctuation could be reduced by applying PCM. Shan et al. set up a test room and studied the influence of a fireplace on the indoor thermal environment [24]. The experiment results showed that a fireplace could reduce indoor air pollution and significantly improve the indoor thermal comfort. A PM level of 10 could be reduced by $72.9 \%$, compared to using a brazier.
Moreover, after 4 hours of burning, the indoor air temperature was $10^{\circ} \mathrm{C}$ higher than the temperature outdoors.

Though the influence of fireplaces on indoor environment quality is well understood, there are few studies related to the influence of different combustion patterns on the thermal performance of heated walls, especially in terms of intermittent combustion. Therefore, in this research, a heated wall was constructed to test its impact on indoor thermal comfort after intermittent combustion. Key parameters including the wall body's surface temperature distribution, indoor air temperature, and indoor relative humidity were measured under different combustion scenarios.

\section{Design of the Heat Recovery System}

A heat recovery system based on the traditional heated wall was designed for potential use in rural areas of central China. The system was comprised of two parts (as shown in Figure 3): a heated wall connected to a cooking stove (which could be replaced in the future with an innovative, highly energy efficient biomass stove) and a fireplace. Both were connected at different heights to a chimney. All inlets and outlets could be shut by iron plates. The heat recovery system could be transformed from one mode to another, simply by controlling these iron plates (Figure 4).

During winter days, the heated wall's inlets and outlets could be left open when users were cooking. The hot flue gas would then heat the wall body (built with bricks, rammed earth, or adobe, and thus with a relatively high thermal mass) when it flowed through the cavity. The inlets and outlets could then be shut to trap the gas in the flue. The wall body would then release its heat to the adjacent rooms via convection and radiation. In the evening, the heated wall's outlets could be shut and the fireplace outlet opened. This would allow the fireplace to directly heat the room as well as the adjacent wall, releasing heat into the adjacent room even after the fire burned out. In summer, the heated wall's inlet could be shut to let the flue gas discharge directly from the chimney and thus reduce its influence on indoor air temperature.

The positive effect of the heat recovery system could be optimized with a proper building layout (Figure 5). In this research, four rooms were arranged around the heat recovery system; these included a kitchen, bedroom, dining 

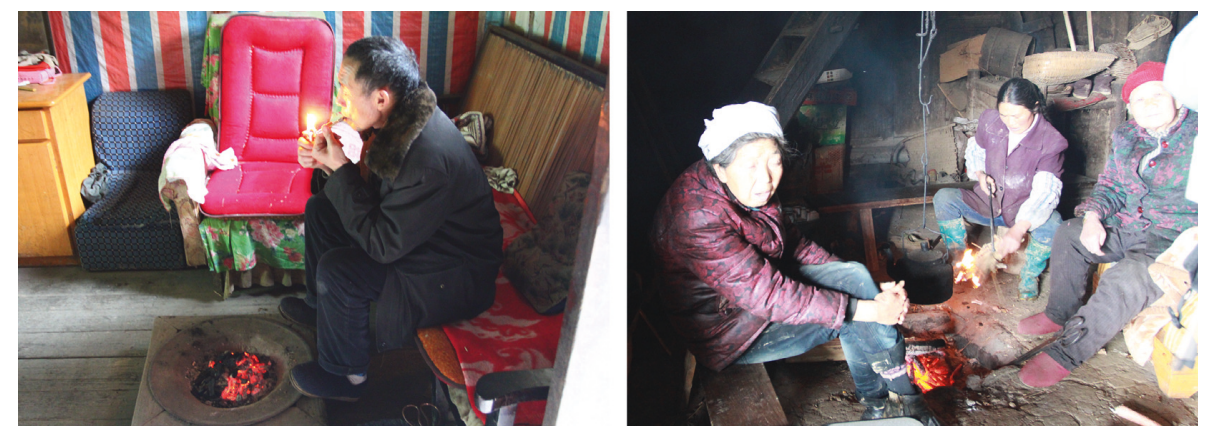

FIGURE 2: Traditional heating and cooking methods commonly used in central and southern China.

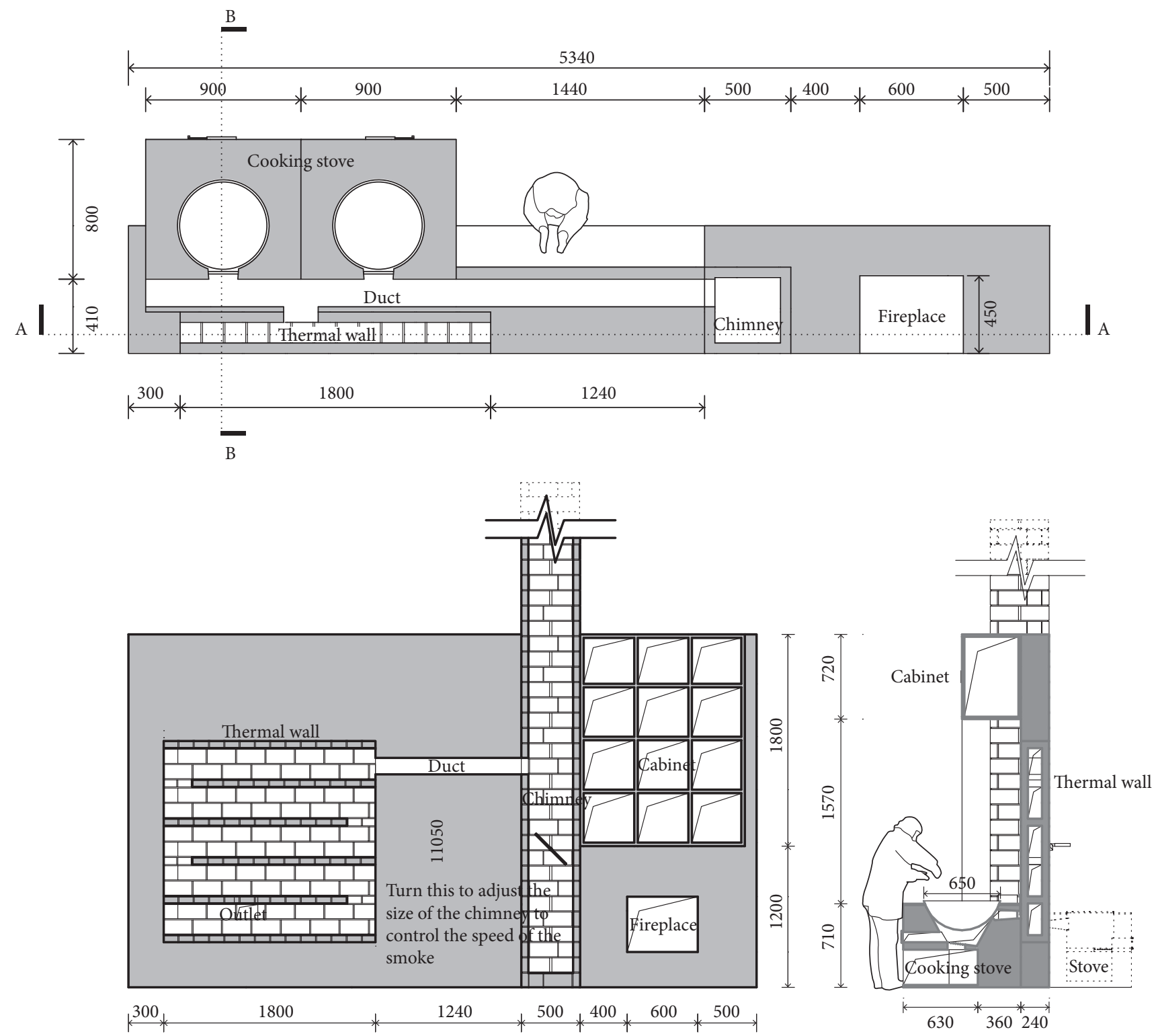

FIGURE 3: The proposed heat recovery system for potential use in rural areas of central China.

room, and living room. Taking the winter mode as an example, the waste heat generated by the cooking stove was recovered and released into the dining room by the heated wall. In the evening, the fireplace heated the living room; meanwhile, the wall between the bedroom and living room was also heated, providing an acceptable air temperature in 


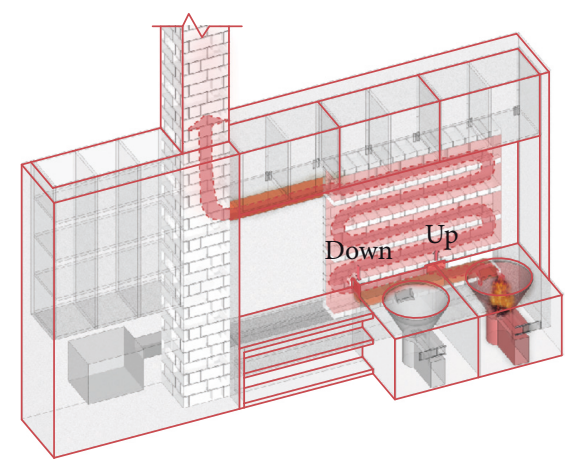

(a)

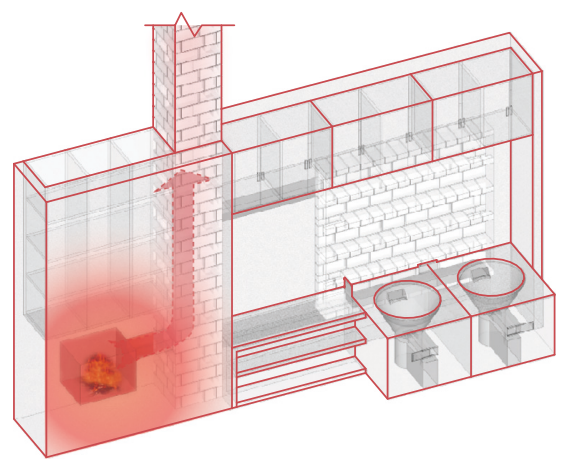

(b)

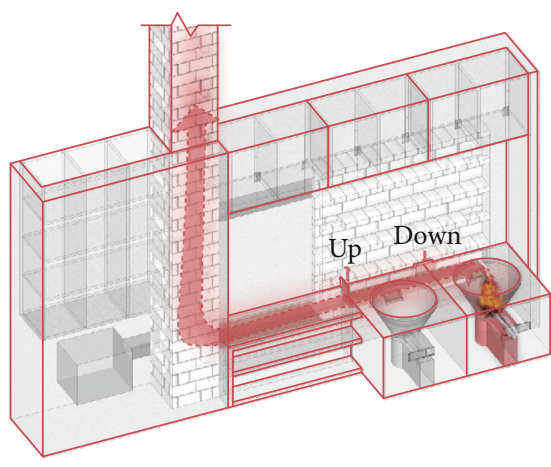

(c)

FIGURe 4: Operation modes for the heat recovery system, applied in different seasons. (a) Winter mode, heating with heated wall; (b) winter mode, heating with fireplace; and (c) winter mode, cooking without enabling the heated wall.

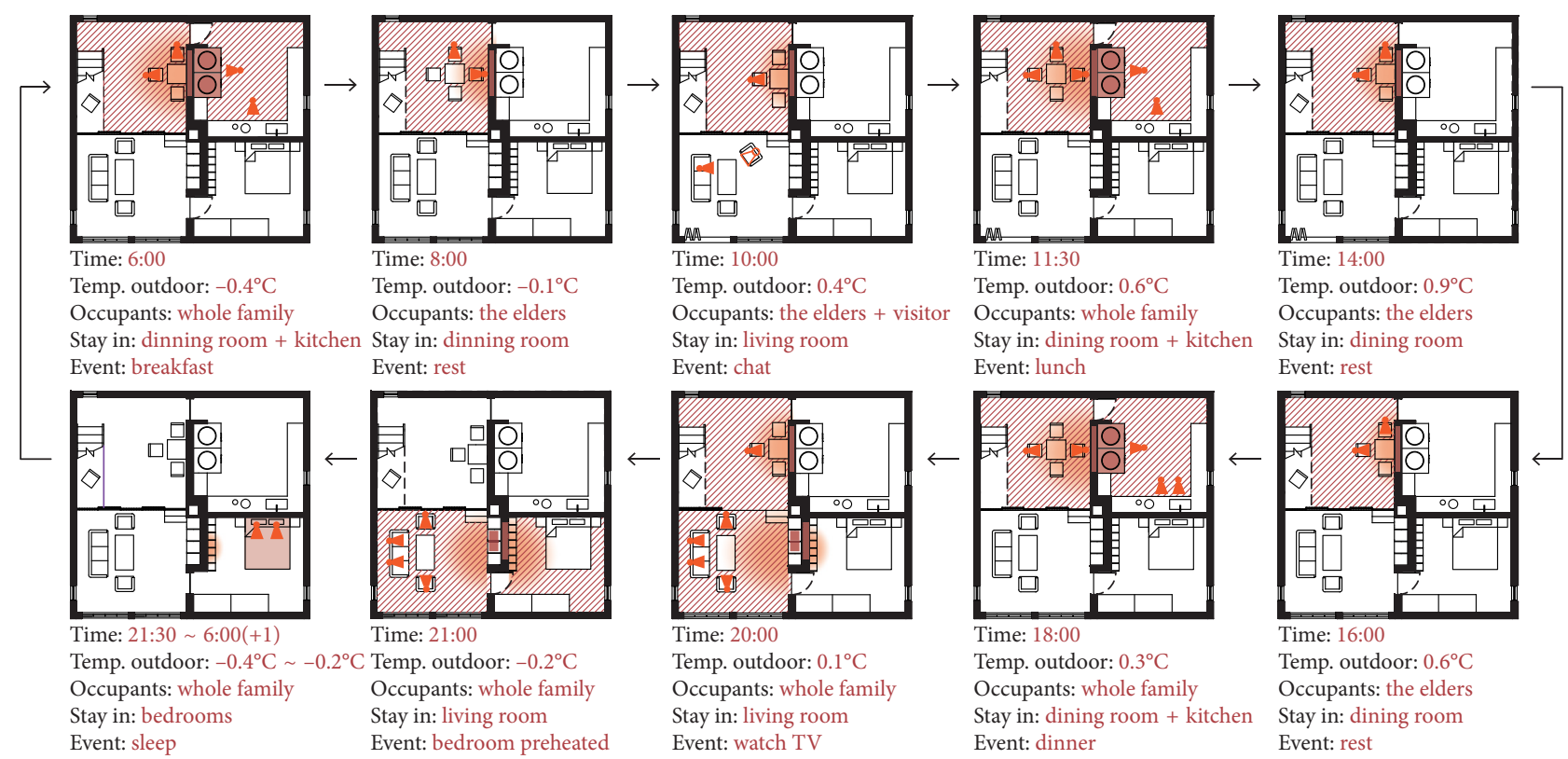

FIGURE 5: Prototype layout for applying the heat recovery system (winter mode).

the bedroom for sleeping. In this way, indoor thermal comfort was, to a certain extent, improved but without increasing energy consumption.

\section{Experiment Setup}

In order to verify the influences of the heated wall on indoor thermal comfort and temperature distribution across the wall's surface, two identical test rooms were set up in Beijing, China. A heated wall was constructed in one of the test rooms to establish a comparative study. The physical dimensions and building materials of both rooms were identical. The eastern and western walls were $3.2 \mathrm{~m}$, and the northern and southern walls were $4.5 \mathrm{~m}$. The storey height was $2.5 \mathrm{~m}$. The flat roof was equipped with a simple suspended ceiling. The doors and windows were installed on the southern side. The window size was $1 \mathrm{~m} \times 1 \mathrm{~m}$, and the door opening was $0.9 \mathrm{~m} \times 1.9 \mathrm{~m}$. The walls were comprised of
$240 \mathrm{~mm}$-thick bricks without a thermal insulation layer. The doors and windows were composed of aluminum alloy door frames and single-pane glass. The wood combustion stove and chimney were located on the southern, outdoor side of the test room. The heated wall was adjacent to the western wall. The heated wall's inlet and outlet were set up to the south. The heated wall was constructed using bricks $1.3 \mathrm{~m}$ in height, $2.1 \mathrm{~m}$ in width, $240 \mathrm{~mm}$ in thickness, $60 \mathrm{~mm}$ for the two-sided wall surface, and $120 \mathrm{~mm}$ for the cavity. The cavity was divided into two zones by a smoke baffle plate. The heated wall was of a single-side heat dissipation type (Figure 6). To avoid the influence of direct solar radiation on indoor temperature, the room with the heated wall (referred to hereafter as the experiment room) and the room without the heated wall (referred to hereafter as the comparison room) were positioned close to the north side of a three-floor structure. During the testing period, the building's envelope received no direct solar radiation from any direction. 


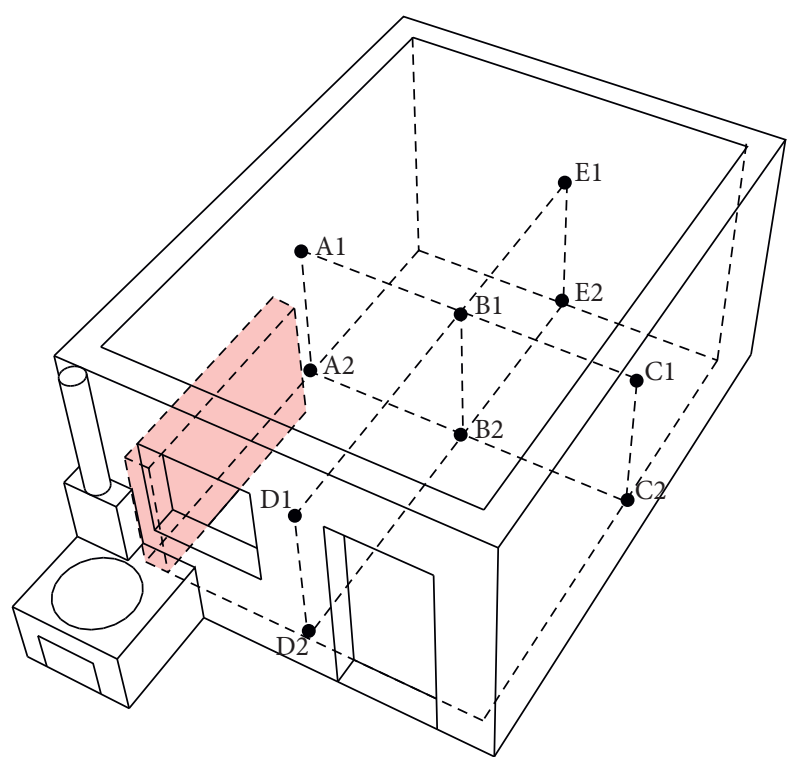

(a)

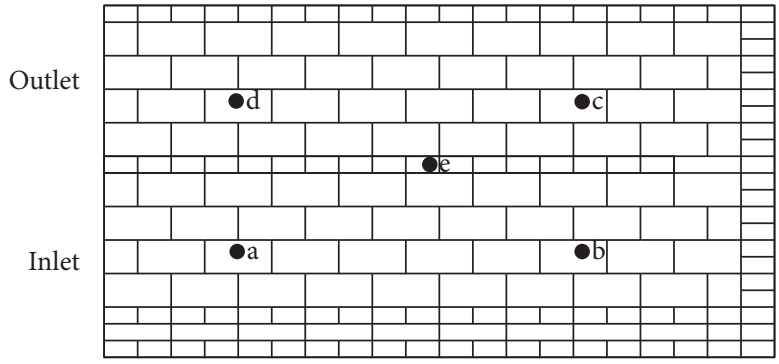

(c)

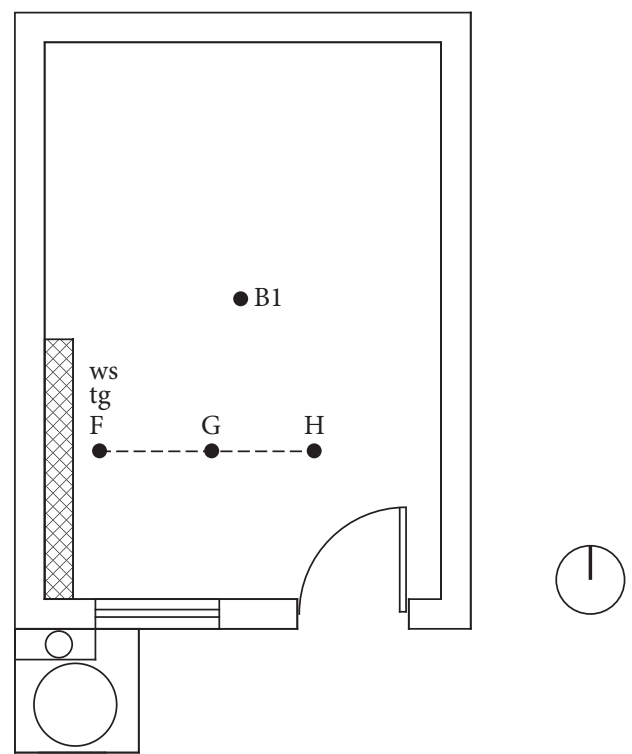

(b)

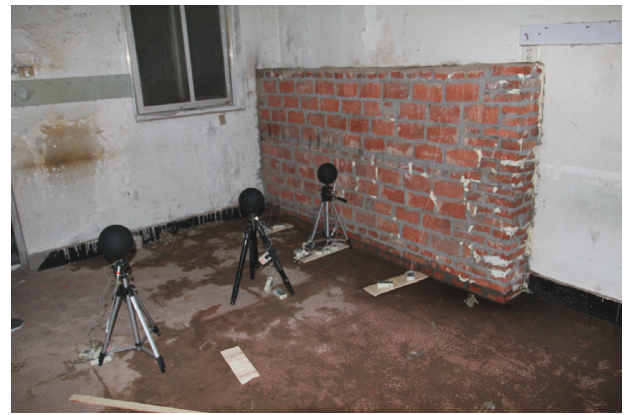

(d)

FIgURE 6: Layout of the test room and testing point arrangement: (a) axonometric view, (b) plan view, and (c, d) heated wall.

Cooking patterns were studied to support the experiment setup. Table 1 shows the seasonal variation in the number of daily meals. In summer, $22.8 \%$ of respondents have two meals per day, while in winter that number has risen to $43.9 \%$. That is, $26.3 \%$ of respondents change their eating schedule according to the seasons. As for the average time spending on cooking (Figure 7), the cooking time in summer is $40.8 \mathrm{~min}$ on average, while it increases to $60.9 \mathrm{~min}$ in winter. According to field survey, firewood and liquefied petroleum gas (LPG) are the main energy sources for cooking. The average amount of firewood consumption for each meal is $7.1 \mathrm{~kg}$ for summer and $9.4 \mathrm{~kg}$ for winter.

Three testing scenarios were established, as follows: Tests 1 and 2 simulated actual cooking patterns, including two or three intermittent combustions per day. Test 1 continued for 24 hours, with two meals per day. Test 2 was similar but extended for two days; the first day involved two meals and the second day involved three. The cooking time and duration were based on previous field studies [21]. Test 3 involved a one-time combustion in order to determine the heated wall's surface temperature distribution and influence on the indoor thermal environment in a single heat transfer process (Table 2). Tests were conducted intermittently from
TABLE 1: Seasonal variation in the number of daily meals.

\begin{tabular}{lcccc}
\hline \multirow{2}{*}{$\begin{array}{l}\text { Number of } \\
\text { daily meals }\end{array}$} & Frequency & $\begin{array}{c}\text { Valid } \\
\text { percent (\%) }\end{array}$ & Frequency & $\begin{array}{c}\text { Valid } \\
\text { percent }\end{array}$ \\
\hline 2 times/day & 9 & 15.8 & 23 & $40.4 \%$ \\
3 times/day & 48 & 84.2 & 34 & $59.6 \%$ \\
\hline
\end{tabular}

November of 2014 to April of 2015. During the testing period, the doors and windows were kept closed.

All the testing instruments are listed in Table 3. There were seven measurement points set on the surface of the heated wall (i.e., points F-L in Figure 6). Air temperature and humidity data loggers were also installed in both of the two test rooms, as well as outdoors (i.e., points A-E). The data sampling interval was $5 \mathrm{~min}$. Infrared thermographs of the heated wall's surface were taken during Test 1 at 10 to $120 \mathrm{~min}$ intervals. The outdoor weather conditions during the testing period were as follows. Tests 1 and 2 were conducted in November. The mean outdoor air temperatures were $6.06^{\circ} \mathrm{C}$ and $3.11^{\circ} \mathrm{C}$, respectively. The mean relative humidity levels were $74.59 \%$ and $51.32 \%$, respectively. Test 3 was conducted at the end of March. The mean outdoor air 


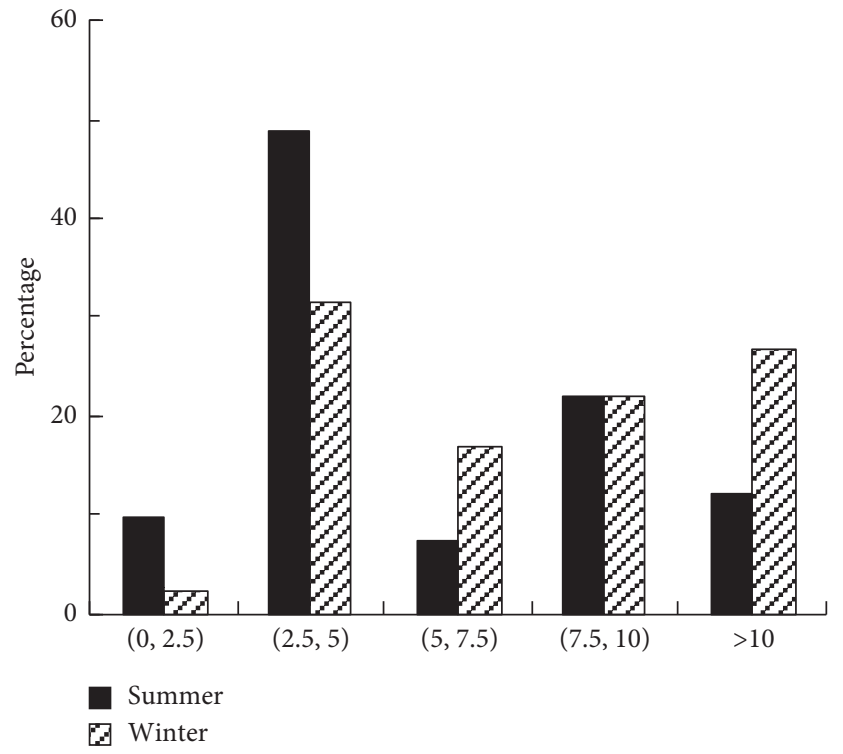

(a)

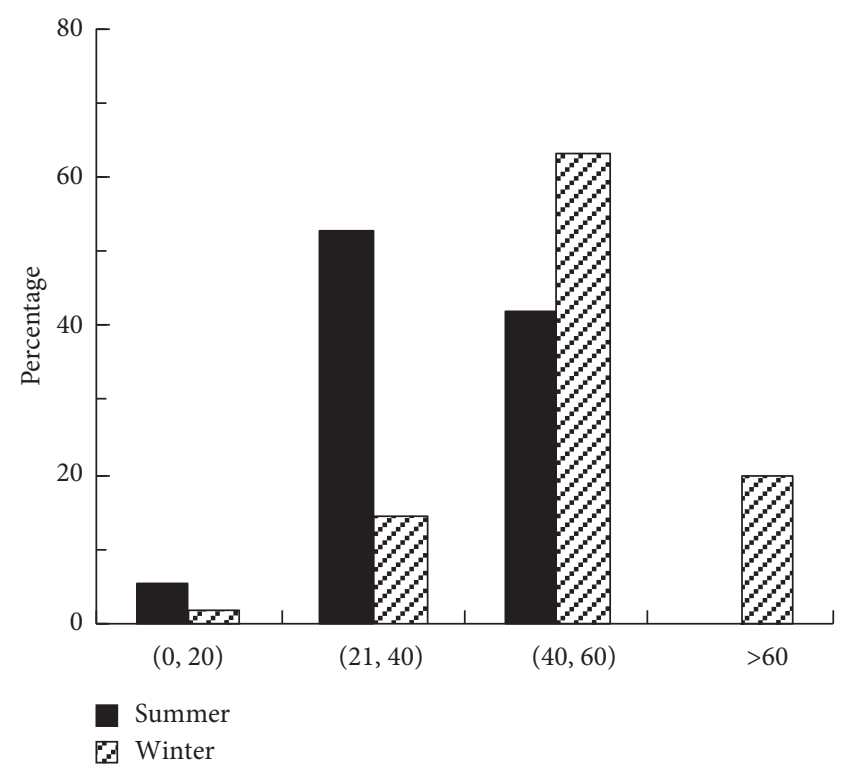

(b)

Figure 7: (a) The average time spending on cooking and (b) the average amount of firewood consumption for each meal.

Table 2: Testing scenarios (Tests 1-3).

\begin{tabular}{|c|c|c|c|c|c|c|c|}
\hline Test & Date & Combustion(s) & $\begin{array}{l}\text { Amount of wood for } \\
\text { one combustion }(\mathrm{kg})\end{array}$ & Number & Ignition & $\begin{array}{l}\text { Time stopped } \\
\text { adding wood }\end{array}$ & $\begin{array}{c}\text { Time outlet } \\
\text { was shut }\end{array}$ \\
\hline Test 1 & 2014-11-23 8:40 22:00 & Two times per day & 7.5 & $1 \mathrm{a}$ & $\begin{array}{c}9: 00 \\
16: 00\end{array}$ & $\begin{array}{c}9: 40 \\
16 \cdot 40\end{array}$ & $\begin{array}{l}10: 10 \\
17 \cdot 05\end{array}$ \\
\hline Test 2 & $\begin{array}{c}2014-11-29,8: 30 \sim 2014-12-1 \\
7: 20\end{array}$ & $\begin{array}{c}\text { Two times for day } 1 \text {, three } \\
\text { times for day } 2\end{array}$ & 7.5 & $\begin{array}{l}2 \mathrm{a} \\
2 \mathrm{~b} \\
2 \mathrm{c} \\
2 \mathrm{~d} \\
2 \mathrm{e}\end{array}$ & $\begin{array}{c}9: 00 \\
16: 00 \\
8: 00 \\
12: 00 \\
19: 00\end{array}$ & $\begin{array}{c}9: 40 \\
16: 40 \\
8: 40 \\
12: 30 \\
19: 35\end{array}$ & $\begin{array}{c}10: 10 \\
17: 05 \\
9: 10 \\
12: 50 \\
19: 55\end{array}$ \\
\hline Test 3 & 2015-3-25 19:30 21:35 & Single combustion & 7.5 & $3 a$ & $19: 45$ & $20: 30$ & $21: 00$ \\
\hline
\end{tabular}

TABLE 3: Testing instruments used in the experiment.

\begin{tabular}{lccc}
\hline Parameter & Instrument & $\begin{array}{c}\text { Measurement } \\
\text { range }\end{array}$ & Resolution \\
\hline $\begin{array}{l}\text { Thermography } \\
\text { VarioCAM HR } \\
\text { inspect }\end{array}$ & $-40 \sim 2000^{\circ} \mathrm{C}$ & $0.05^{\circ} \mathrm{C}$ \\
$\begin{array}{l}\text { W } \\
\text { temperature }\end{array}$ & $\begin{array}{c}\text { WZY-1 } \\
\text { thermocouple }\end{array}$ & $-40 \sim 100^{\circ} \mathrm{C}$ & $0.1^{\circ} \mathrm{C}$ \\
$\begin{array}{l}\text { Relative } \\
\text { humidity }\end{array}$ & $\begin{array}{c}\text { WSZY-1 auto- } \\
\text { logger }\end{array}$ & $-40 \sim 100^{\circ} \mathrm{C}$ & $0.1^{\circ} \mathrm{C}$ \\
\hline
\end{tabular}

temperature was $10.9^{\circ} \mathrm{C}$, while the relative humidity was $35.36 \%$.

\section{Observations and Results}

4.1. Heated Wall Surface Temperature Distribution. Infrared thermographs were taken to analyze the temperature distribution of the heated wall's surface (Figure 8).
Before the first combustion began (8:00-9:00), the wall's surface temperature distribution was relatively even. The mean temperature was $11.18^{\circ} \mathrm{C}$, and the temperature range was $8.61^{\circ} \mathrm{C}(\mathrm{SD}=1.06)$. Soon after ignition (9:00-10:00), the wall surface temperature began to rise at a gradually increasing speed. Soon after the flame was extinguished, the mean temperature of the wall reached its peak at $36.44^{\circ} \mathrm{C}$, at which point the largest temperature difference on the heated wall's surface was created. The temperature range was as much as $116.03^{\circ} \mathrm{C}(\mathrm{SD}=16.17)$. During combustion, the mean speed of the temperature's rise on the heated wall was $0.37^{\circ} \mathrm{C} / \mathrm{min}$, while the maximum was $0.68^{\circ} \mathrm{C} / \mathrm{min}$. The surface near the inlet had the maximum rising speed, with a mean value of $1.75^{\circ} \mathrm{C} / \mathrm{min}$ and maximum of $2.74^{\circ} \mathrm{C} / \mathrm{min}$. After the flame was extinguished for 15 to $20 \mathrm{~min}$, the surface temperature began to decrease. The mean speed of the temperature decrease was $-0.04^{\circ} \mathrm{C} / \mathrm{min}$. The process for the temperature decrease was much slower than the increase process. The wall temperature near the inlet began to decrease rapidly for one hour after extinguishing, 


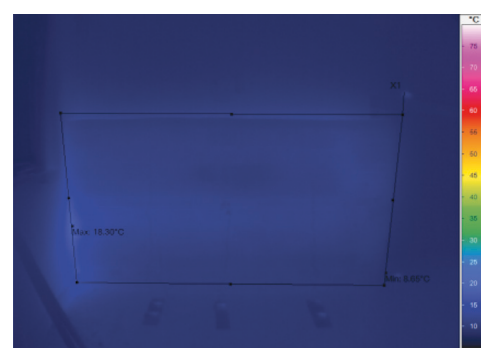

$8: 30$

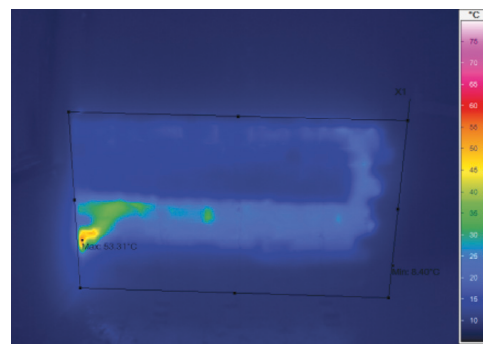

9:30

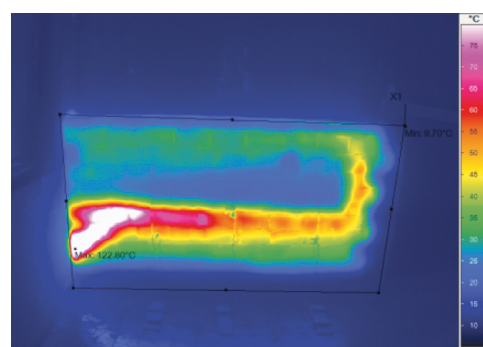

10:00

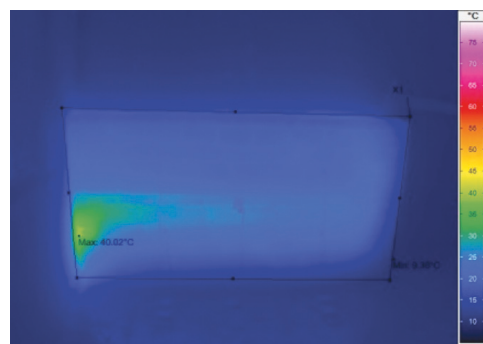

14:00

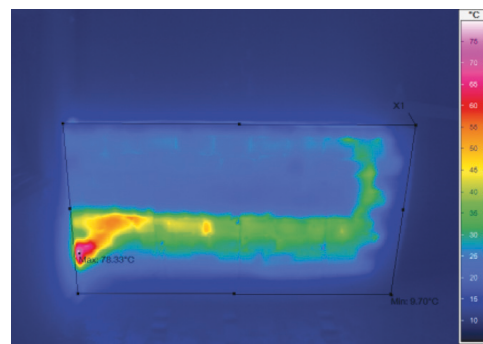

16:30

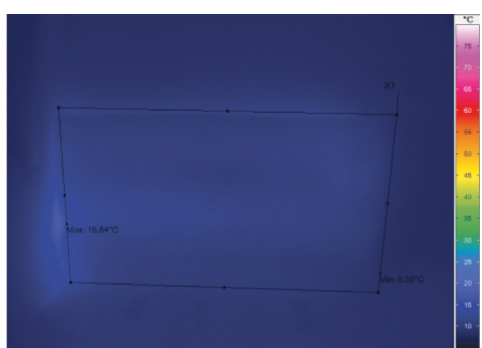

9:00

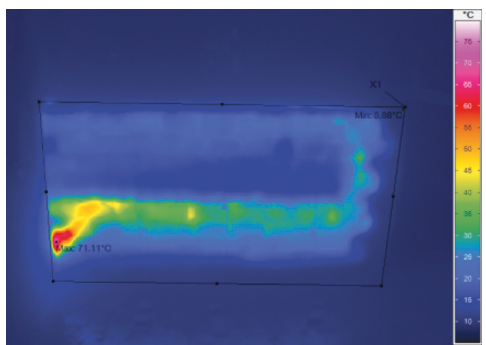

9:40

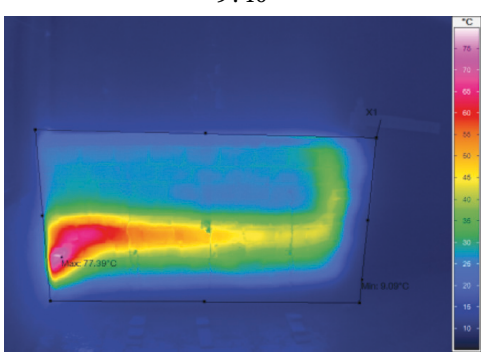

11:00

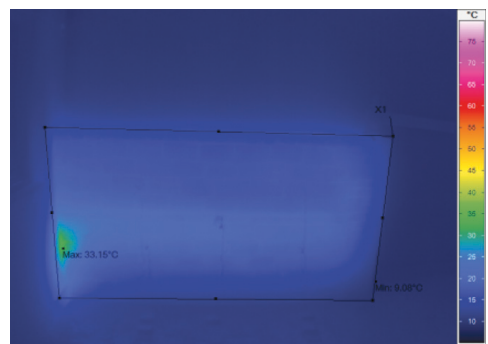

16:00

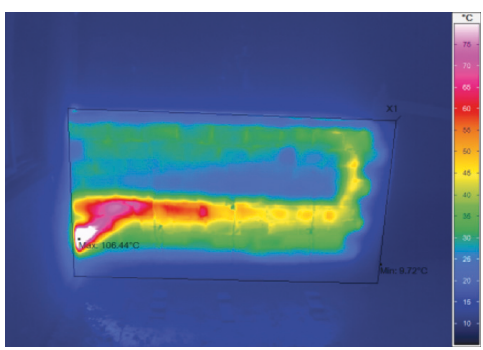

$16: 45$

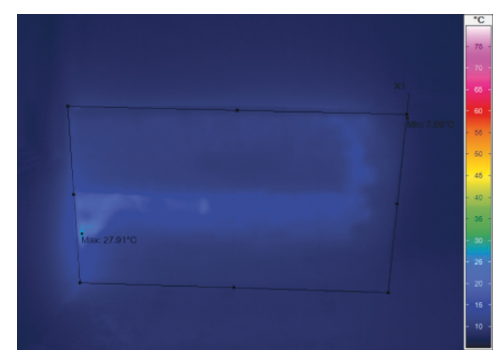

9:15

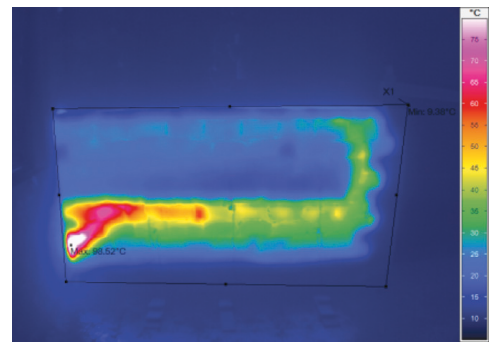

$9: 50$

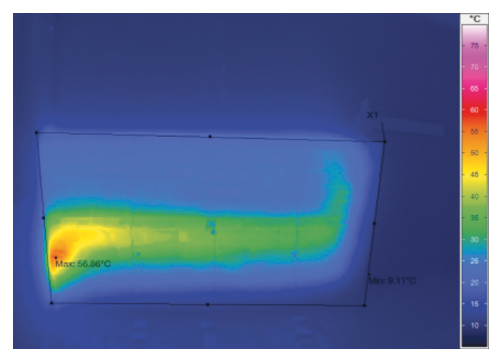

12:00

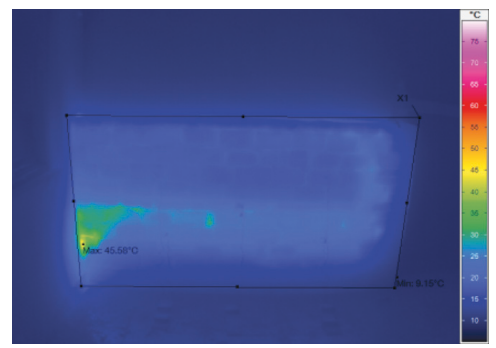

$16: 15$

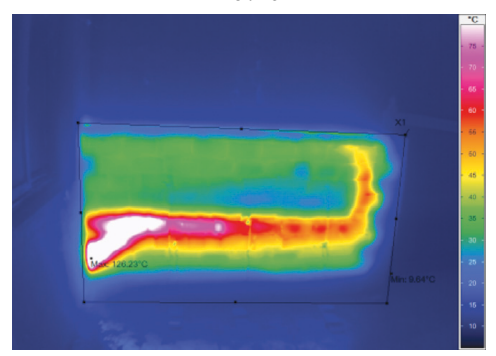

17:00

FiguRE 8: Infrared thermographs of a heated wall's surface (Test 1).

reaching $-0.76^{\circ} \mathrm{C} / \mathrm{min}$. Then, it gradually decreased until the next combustion began. A single combustion increased the mean temperature of the heated wall's surface by 18.99 to $22.11^{\circ} \mathrm{C}$. The mean temperature of the heated wall's surface was still above $20^{\circ} \mathrm{C}$ four hours after extinguishing. It is clear from the infrared thermographs that the heat exchange process between the high-temperature smoke and wall body mainly took place in the lower zone of the flue (Zone 1). The smoke in Zone 1 had a higher temperature and thus more efficient heat exchange with the wall body. The wall temperature significantly increased and the smoke temperature rapidly reduced. The smoke temperature in the upper flue (Zone 2) was lower, and the surface temperature variation of the wall body was relatively small. 
4.2. Influence of Different Combustion Patterns on the Initial Surface Temperature. As previously described, Tests 1, 2, and 3 adopted different combustion patterns. Test 1 included two intermittent combustions at a time interval of $6 \mathrm{~h}$. Test 2 was comprised of five intermittent combustions at intervals of $6 \mathrm{~h}, 15 \mathrm{~h}$ (overnight), $3 \mathrm{~h}$, and $6 \mathrm{~h}$. In Figure 9, we used $\Delta t_{1}$ to represent the amplitude of the temperature variation during a single combustion. The values of $\Delta t_{1}$ at the same measuring points were similar when there was a set amount of fuel. Taking measuring point $\mathrm{F}$ as an example, the values of $\Delta t_{1-\mathrm{F}}$ ranged from $32.0^{\circ} \mathrm{C}$ to $35.4^{\circ} \mathrm{C}$. That is, $\Delta t_{1}$ was mainly determined by the efficiency and energy density of the combustion. The outdoor weather conditions comprised one of the main factors affecting combustion efficiency. When there were higher levels of outdoor air velocity, the value of $\Delta t_{1}$ rose correspondingly.

Though the combustion pattern had little influence on the value of $\Delta t_{1}$, it did have a major impact on the initial and peak temperatures of each combustion. Values for $\Delta t_{2}$ and $\Delta t_{3}$ were used to represent the temperature differences in peak and initial values for the two adjacent combustions, respectively. The combustion patterns included several intermittent combustions (i.e., Tests 1 and 2) and significantly increased the initial and peak temperatures of the heated wall's exterior surface.

In Test 1 , the peak temperature of the second combustion was improved by $4.7^{\circ} \mathrm{C}$. The initial temperature was improved by $6.5^{\circ} \mathrm{C}$, on average. In Test 2 , the $\Delta t_{2}$ values ranged from $2.6^{\circ} \mathrm{C}$ to $9.6^{\circ} \mathrm{C}$, on average. There was a $20.7^{\circ} \mathrm{C}$ increase of the peak surface temperature and a $14.6^{\circ} \mathrm{C}$ increase in the initial surface temperature under the cumulative effect of five intermittent combustions (Table 4).

4.3. Critical Time Nodes for the Heated Wall's Dynamic Temperature Process. Three critical time nodes $\left(t_{\mathrm{i}}, t_{\mathrm{s}}\right.$, and $\left.t_{\mathrm{f}}\right)$ were identified to describe the combustion process. Specifically, the times of ignition, feeding fuel stopped, and fire burning out were represented by $t_{\mathrm{i}}, t_{\mathrm{s}}$, and $t_{\mathrm{f}}$, respectively (Figure 10). To describe the dynamic thermal process of the heated wall surface's temperature over time, the temperature change rate $a_{\mathrm{i}}\left({ }^{\circ} \mathrm{C} / \mathrm{min}\right)$ was calculated by the following equation (Equation (1) and Figure 10):

$$
a_{\mathrm{i}}=\frac{T_{\mathrm{i}+1}-T_{\mathrm{i}}}{t} \text {. }
$$

Five time nodes $\left(t_{1}-t_{5}\right)$ were extracted from the temperature change rate curve (Figure 10(b)), where at the turning point, $t_{1}$, the exterior surface temperature began to rise. The temperature change rate reached its peak value at $t_{2}$ and fell back to $0^{\circ} \mathrm{C} / \mathrm{min}$ at $t_{3}$. This meant that the surface temperature of the heated wall's body began to decrease. The rate of descent increased until it reached $t_{4}$. Then, the temperature descent slowed to a relatively steady state after $t_{5}$.

After igniting the fuelwood $\left(t_{\mathrm{i}}\right)$ for 10 to $20 \mathrm{~min}$, the heated wall's temperature began to increase $\left(t_{1}\right)$. Then, the temperature increase sped up. After ceasing to add firewood to stove $\left(t_{\mathrm{s}}\right)$ for 5 to $20 \mathrm{~min}$, the rate of the temperature increase reached its peak value $\left(t_{2}\right)$. After the fire burning out and closing the flue $\left(t_{\mathrm{f}}\right)$ for 10 to $25 \mathrm{~min}$, the heated wall's temperature reached its maximum value $\left(t_{3}\right)$. At this time, the temperature difference between the measurement points also reached its maximum. Then, the wall temperature began to decline. After 5 to $30 \mathrm{~min}$, the speed of the temperature reduction reached its maximum $\left(t_{4}\right)$. After the combustion was finished for $3 \mathrm{~h}$ to $4 \mathrm{~h}$, the wall temperature stabilized $\left(t_{5}\right)$ until the next combustion was initiated.

\subsection{Influences of the Heated Wall on the Indoor Thermal} Environment. During the entire testing period, the air temperature in the experiment room was higher than that in outdoors or in the comparison room (Figure 11). Test 1 yielded a mean outdoor air temperature of $6.9^{\circ} \mathrm{C}$, while the mean air temperatures in the experiment and comparison rooms were $10.9^{\circ} \mathrm{C}$ and $7.6^{\circ} \mathrm{C}$, respectively. Test 2 had a mean outdoor air temperature of $4.9^{\circ} \mathrm{C}$. The mean air temperature in the experiment room was $9.9^{\circ} \mathrm{C}$, while the mean air temperature in the comparison room was only $5.9^{\circ} \mathrm{C}$.

There was an approximate $0.5 \mathrm{~h}$ time lag between the rising indoor air temperature and initiation of combustion. After closing the inlet and outlet of the flue, the indoor temperature began to rapidly increase. It reached its peak about $1 \mathrm{~h}$ after the fire burned out, indicating that highefficiency heat exchange was enhanced by this process.

It was also determined that, with the same quantity of fuel and burn time, the temperature's rising amplitude during each combustion process remained relatively stable, between $2.1^{\circ} \mathrm{C}$ and $3.0^{\circ} \mathrm{C}$. Furthermore, the tests showed that the heated wall operated under an intermittent combustion pattern, which simulated the cooking pattern commonly adopted by rural Chinese. This had a significant effect on improving the indoor thermal comfort. In Test 1 , the indoor air temperature was $8.7^{\circ} \mathrm{C}$ before the first combustion started. The indoor air temperature was increased by $1.5^{\circ} \mathrm{C}$ before the second combustion started, while the air temperature in the comparison room only improved by $0.6^{\circ} \mathrm{C}$ during the same period. In Test 2 , after five combustions (represented by five cooking activities), the indoor temperature increased from $6.1^{\circ} \mathrm{C}$ to $13.3^{\circ} \mathrm{C}$. During the same period, the indoor temperature of the comparison room decreased to $5.7^{\circ} \mathrm{C}$ from $6.2^{\circ} \mathrm{C}$. It was affected by the outdoor air's temperature reduction.

The relative air humidity in the experiment room was relatively higher than that in the comparison room, which can be explained by the increase in absolute humidity due to the combustion activity (Figures 12 and 13). During each combustion, the absolute indoor humidity of the experiment room increased by 0.4 to $1.4 \mathrm{~g} / \mathrm{m}^{3}$. As compared to the room without a heated wall, the indoor absolute humidity was $0.3-2.7 \mathrm{~g} / \mathrm{m}^{3}$ higher in the experiment room. One factor affecting this phenomenon was the relatively high water content of the firewood and building materials used to build the heated wall. 

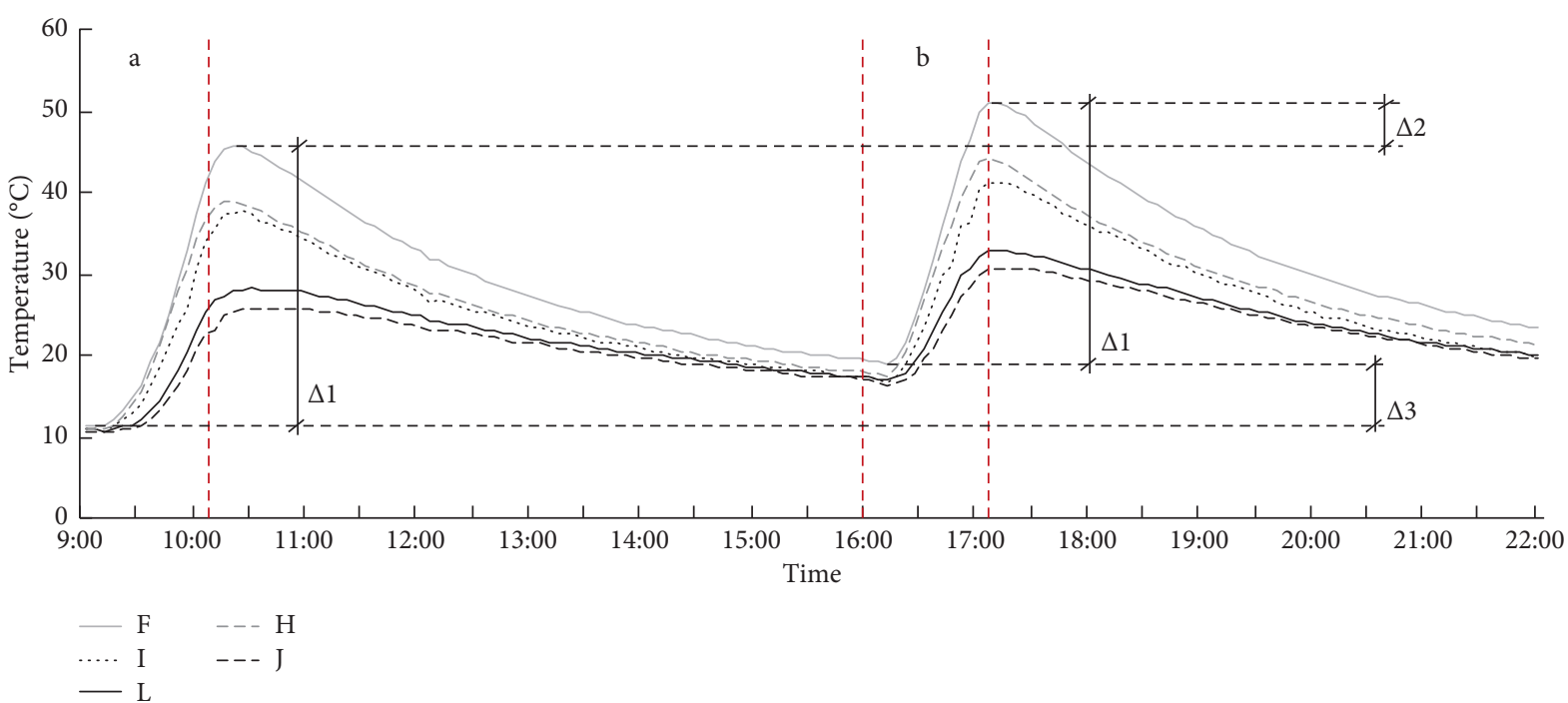

(a)

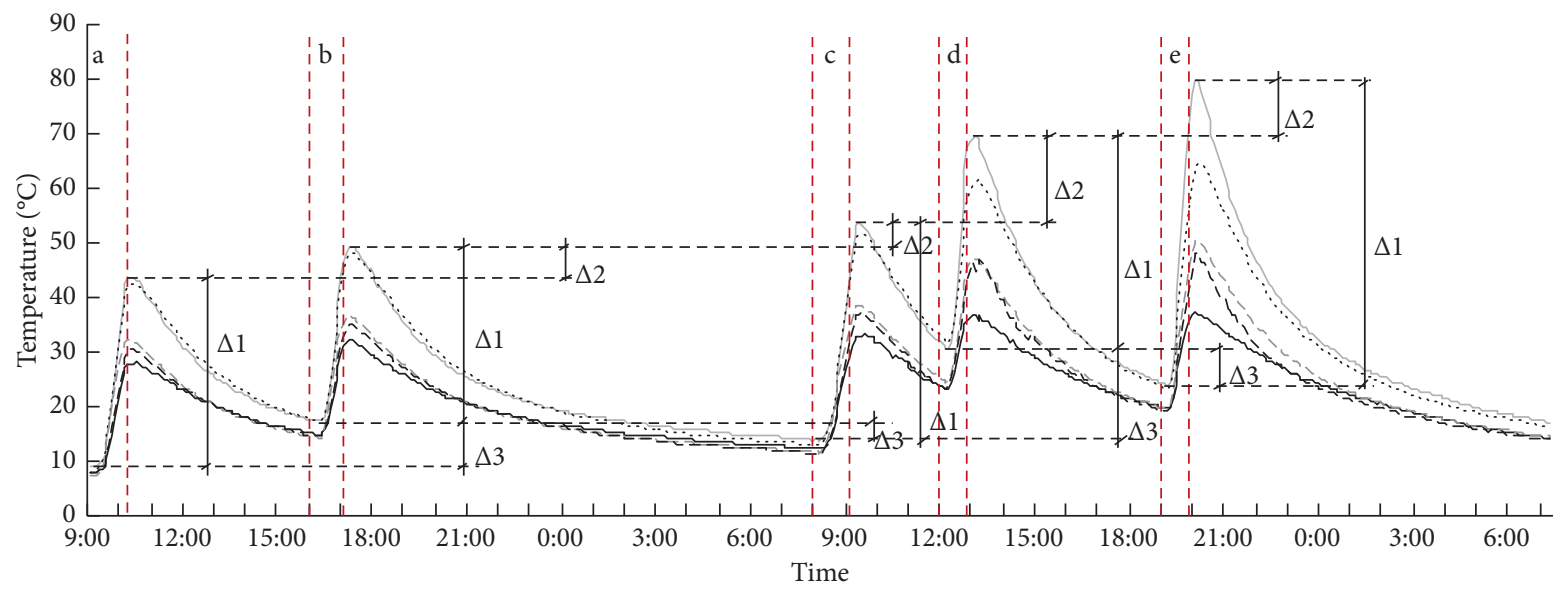

$$
\begin{array}{lll} 
& \mathrm{F} & ---\mathrm{H} \\
\ldots . & \mathrm{I} & ---\mathrm{J} \\
-\mathrm{L} &
\end{array}
$$

(b)

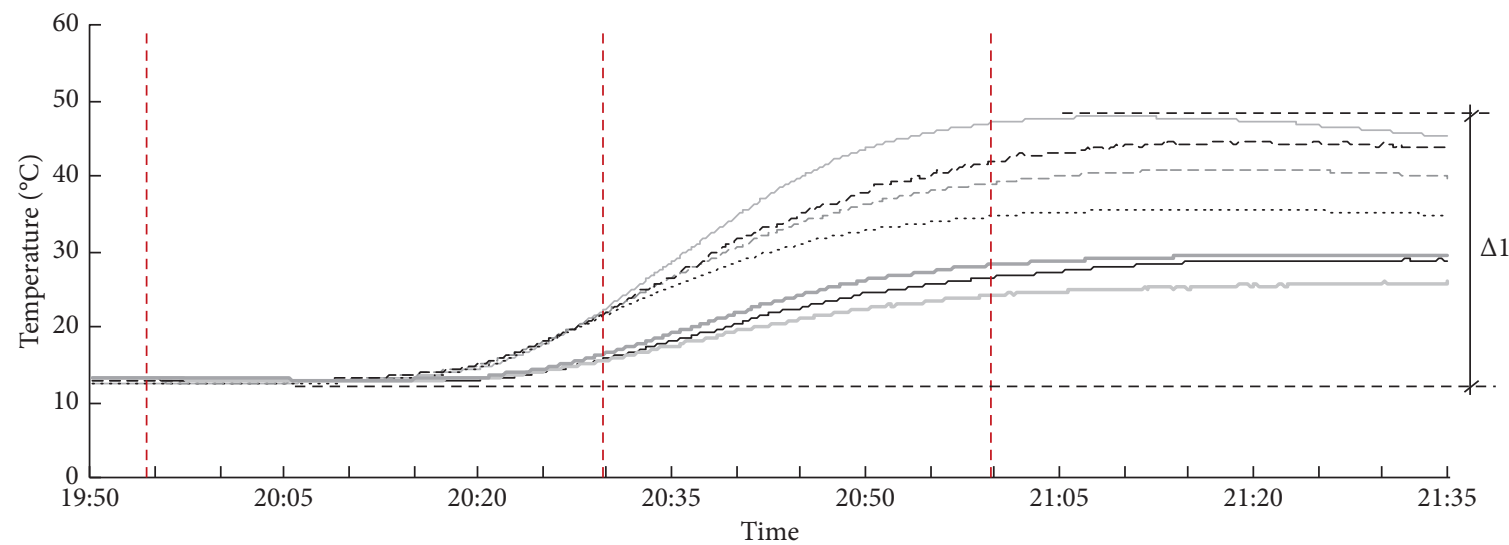

$$
\begin{array}{ll}
-\mathrm{F} & --\mathrm{I} \\
\ldots \ldots \mathrm{H} & -\mathrm{K} \\
-\mathrm{J}_{-} & -\mathrm{G}
\end{array}
$$

(c)

Figure 9: Heated wall temperature distributions: (a) Test 1, (b) Test 2, and (c) Test 3. 
Table 4: Peak $\left(\Delta t_{2}\right)$ and initial temperature differences $\left(\Delta t_{3}\right)$ of the heated wall surface.

\begin{tabular}{|c|c|c|c|c|c|c|c|}
\hline \multirow{2}{*}{ Measuring point } & & \multirow{2}{*}{$\begin{array}{c}\text { Test } 1 \\
1 \mathrm{~b}-1 \mathrm{a}\left({ }^{\circ} \mathrm{C}\right)\end{array}$} & \multicolumn{5}{|c|}{ Test 2} \\
\hline & & & $2 \mathrm{~b}-2 \mathrm{a}\left({ }^{\circ} \mathrm{C}\right)$ & $2 \mathrm{c}-2 \mathrm{~b}\left({ }^{\circ} \mathrm{C}\right)$ & $2 \mathrm{~d}-2 \mathrm{c}\left({ }^{\circ} \mathrm{C}\right)$ & $2 \mathrm{e}-2 \mathrm{~d}\left({ }^{\circ} \mathrm{C}\right)$ & Cumulative total $\left({ }^{\circ} \mathrm{C}\right)$ \\
\hline \multirow{2}{*}{$\mathrm{F}$} & $\Delta t_{2}$ & 5.4 & 5.5 & 4.8 & 15.9 & 10 & 36.2 \\
\hline & $\Delta t_{3}$ & 7.6 & 8.4 & -3.5 & 16.9 & -6.7 & 15.1 \\
\hline \multirow{2}{*}{$\mathrm{H}$} & $\Delta t_{2}$ & 5.1 & 4.4 & 1.9 & 8.8 & 3.2 & 18.3 \\
\hline & $\Delta t_{3}$ & 6.7 & 7.3 & -2.8 & 13 & -5 & 12.5 \\
\hline \multirow{2}{*}{ I } & $\Delta t_{2}$ & 3.6 & 5.6 & 3.2 & 10 & 3.3 & 22.1 \\
\hline & $\Delta t_{3}$ & 6.1 & 9.4 & -4.4 & 18.7 & -8.3 & 15.4 \\
\hline \multirow{2}{*}{$\mathrm{J}$} & $\Delta t_{2}$ & 5 & 4.4 & 2.2 & 9.8 & 1.1 & 17.5 \\
\hline & $\Delta t_{3}$ & 6 & 13.9 & -3.2 & 11.9 & -4.3 & 18.3 \\
\hline \multirow{2}{*}{$\mathrm{L}$} & $\Delta t_{2}$ & 4.6 & 4.3 & 1.1 & 3.4 & 0.5 & 9.3 \\
\hline & $\Delta t_{3}$ & 6.3 & 7.1 & -2.7 & 10.9 & -3.5 & 11.8 \\
\hline
\end{tabular}

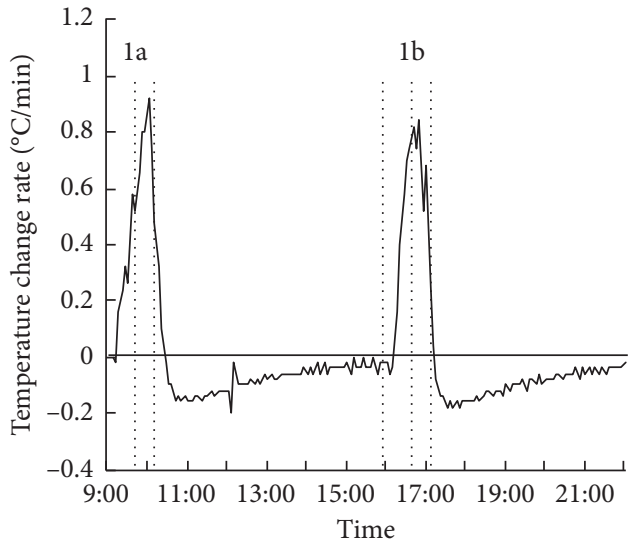

(a)

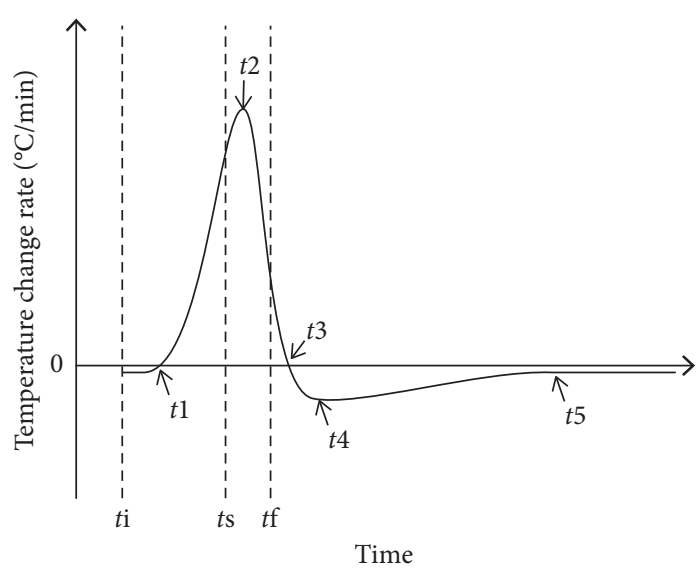

(b)

FIgURE 10: (a) Test 1 temperature change rate at point F on the heated wall; (b) time node diagram of the temperature change rate of the heated wall (measuring point $\mathrm{F}$ ).

\section{Conclusions}

In this research, the proposed heat recovery system design evolved from the Chinese traditional heated wall. Two test rooms were set up and key variables measured to evaluate the thermal performance of the improved heated wall. The following conclusions were drawn based on the study results:

(1) The improved heated wall system consists of a hollow wall, biomass stove, and a fireplace. With a proper building layout, this system can support a more comfortable and healthier indoor environment without extra energy consumption. Main living spaces should be arranged around the heated wall system in coordination with the local life pattern.

(2) As can be observed from the infrared thermographs, the heat exchange process between the hightemperature smoke and wall body mainly took place in the lower zone of the flue. The temperature distribution of the heated wall's exterior surface was highly nonuniform. The temperature range was as much as $116.03^{\circ} \mathrm{C}$.
(3) The temperature rises in the heated wall's surface during each combustion were relatively the same when there was a set amount of fuel. The amplitude of the temperature rise was mainly determined by the efficiency and energy density of the combustion. The combustion pattern (including combustion times, intervals, and fuel quantity) had a major impact on the initial and peak values of the wall body's surface temperature during each combustion.

(4) Five critical 4ime nodes $\left(t_{1}-t_{5}\right)$ were extracted from the temperature change rate curve to describe the dynamic changes in the heated wall's surface temperature. The process was divided into the following stages: $t_{1}-t_{2}$ represent the acceleration of surface temperature increments, $t_{2}-t_{3}$ were the deceleration of surface temperature increments, $t_{3}-t_{4}$ were the acceleration of surface temperature decrements, $t_{4}-t_{5}$ were the deceleration of surface temperature decrements, and $t_{5}$ was a relatively stable state.

(5) Indoor temperature can be increased by $3.3-4.0^{\circ} \mathrm{C}$ (as compared to the control room) with the installation of a heated wall. However, the relative and 

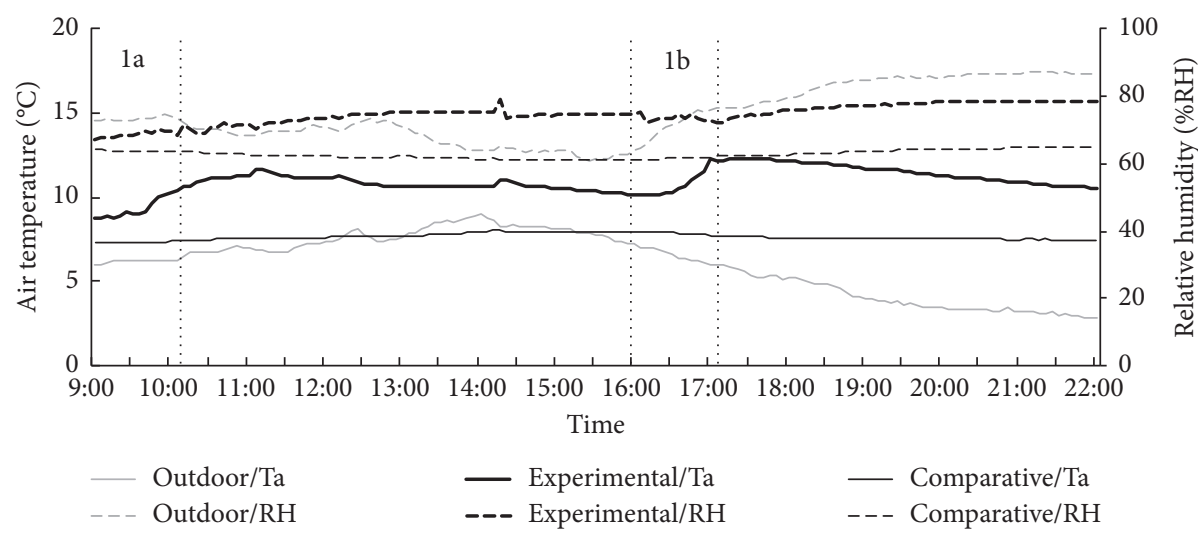

(a)

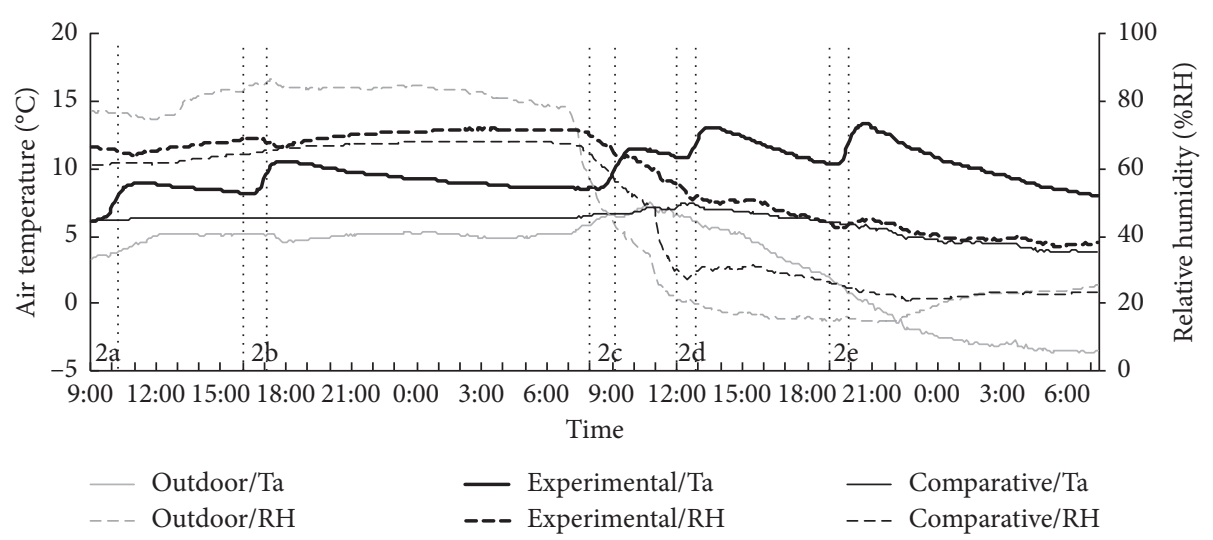

(b)

FIgURE 11: Air temperature and humidity variations: (a) Test 1 and (b) Test 2.

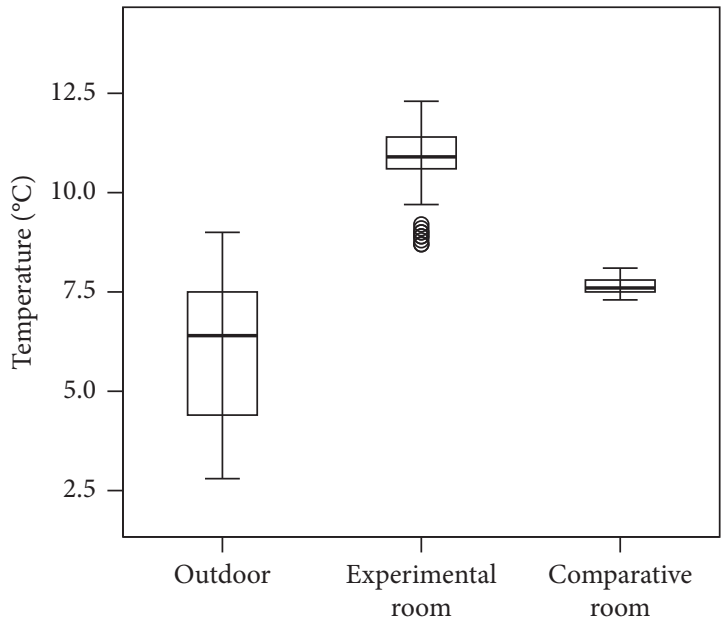

(a)

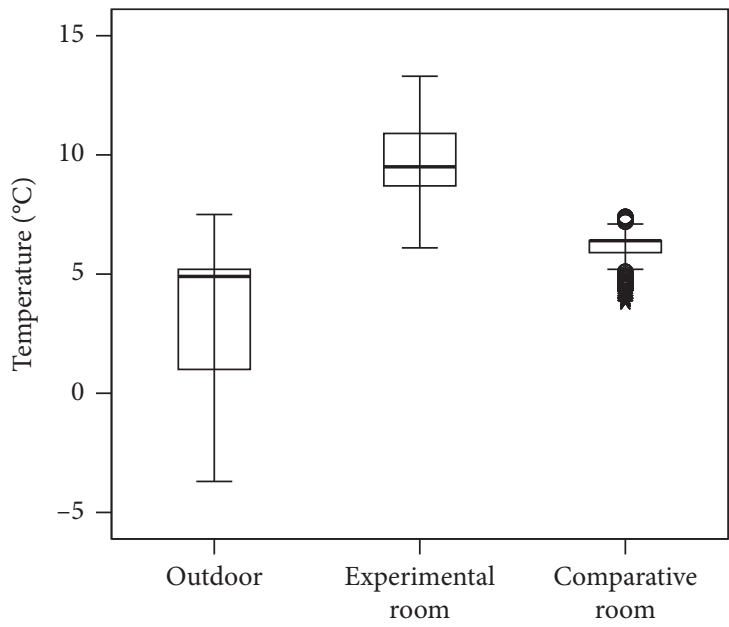

(b)

Figure 12: Continued. 


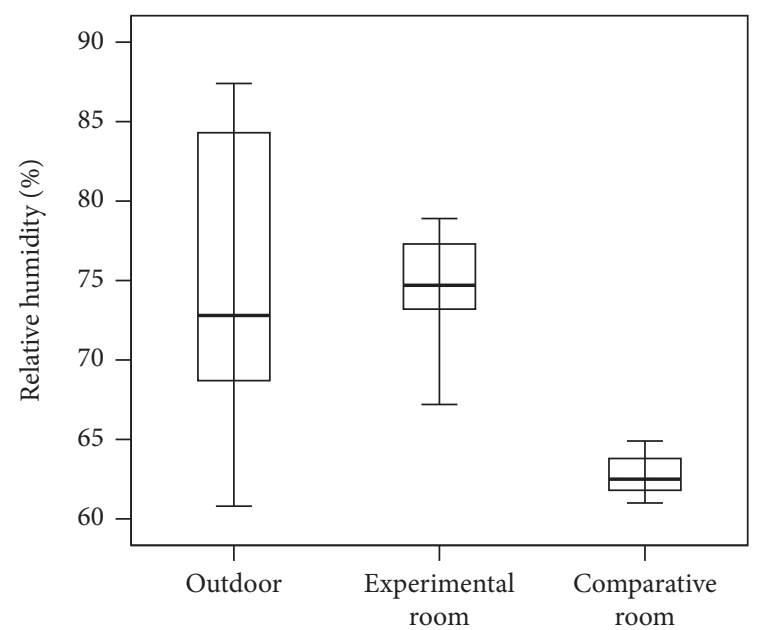

(c)

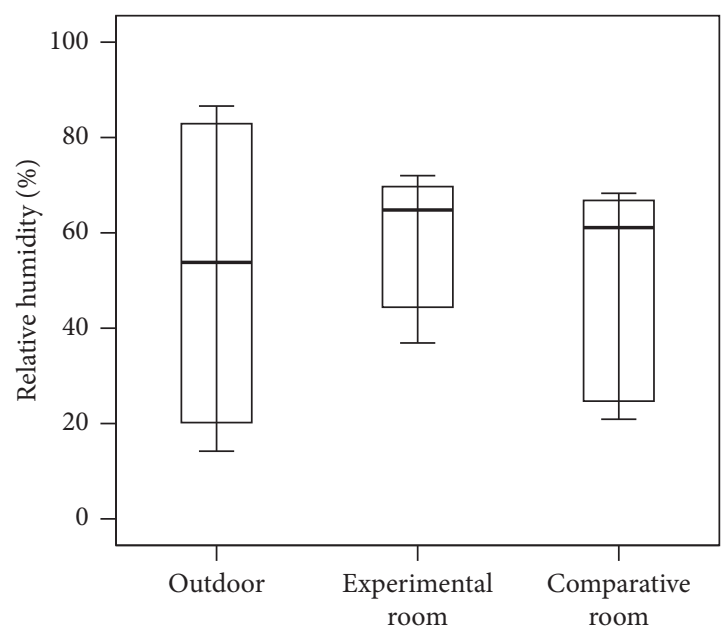

(d)

Figure 12: Outdoor and indoor temperatures and humidity variations: (a, c) Test 1; (b, d) Test 2.

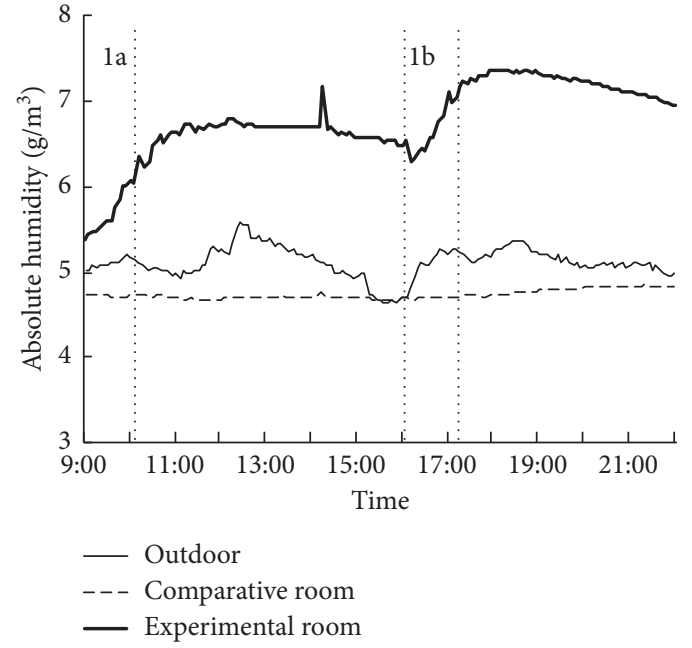

(a)

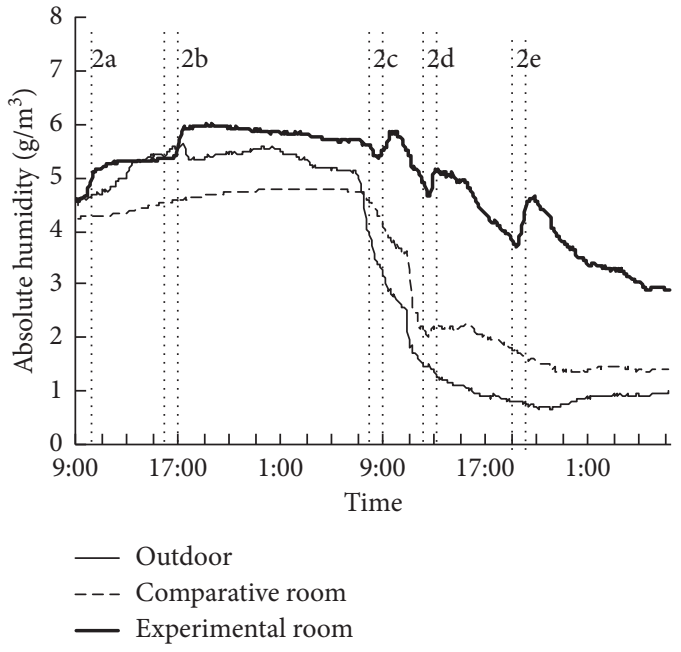

(b)

FIgURE 13: Absolute humidity variations: (a) Test 1 and (b) Test 2.

absolute humidity values in the experiment room were relatively higher than those in the comparison room, which can be explained by the high water content of the firewood and building materials used to build the heated wall.

\section{Nomenclature}

$\Delta t_{1}$ : Amplitude of temperature variation during one combustion ${ }^{\circ} \mathrm{C}$

$\Delta t_{2}$ : Temperature difference in peak value between two adjacent combustions ${ }^{\circ} \mathrm{C}$

$\Delta t_{3}$ : Temperature difference in initial value between two adjacent combustions ${ }^{\circ} \mathrm{C}$

$T_{i}$ : $\quad$ Ignition of the fuelwood

$T_{s}$ : Firewood no longer added

$T_{\mathrm{f}}$ : Open fire stopped and flue closed

$t_{1}$ : Beginning of the temperature rise in the wall $t_{2}$ : Peak speed of the temperature increase reached

$t_{3}$ : Beginning of wall temperature reduction and peak wall temperature reached

$t_{4}$ : Peak temperature reduction reached

$t_{5}$ : Tendency towards stable wall temperature

$a_{i}$ : Temperature change rate at time $i^{\circ} \mathrm{C} / \mathrm{min}$

$T_{i}$ : Surface temperature of the heated wall's exterior surface at time $i^{\circ} \mathrm{C}$

$\Delta t$ : Data sampling interval in min.

\section{Data Availability}

The datasets generated during and/or analyzed during the current study are available from the corresponding author on reasonable request.

\section{Conflicts of Interest}

The authors declare that they have no conflicts of interest. 


\section{Acknowledgments}

This project was supported by the Fundamental Research Funds for the Central Universities (Project no. 2017JC07), the Fundamental Research Funds for Beijing University of Civil Engineering and Architecture (Project no. X18137), and Beijing Advanced Innovation Center for Future Urban Design, Beijing University of Civil Engineering and Architecture (Project no. UDC2018010411).

\section{References}

[1] Z. Chowdhury, L. Campanella, C. Gray et al., "Measurement and modeling of indoor air pollution in rural households with multiple stove interventions in Yunnan, China," Atmospheric Environment, vol. 67, pp. 161-169, 2013.

[2] E. T. Gall, E. M. Carter, C. M. Earnest, and B. Stephens, "Indoor air pollution in developing countries: research and implementation needs for improvements in global public health," American Journal of Public Health, vol. 103, no. 4, pp. e67-72, 2013.

[3] C. L'Orange, J. Volckens, and M. DeFoort, "Influence of stove type and cooking pot temperature on particulate matter emissions from biomass cook stoves," Energy for Sustainable Development, vol. 16, pp. 448-455, 2012.

[4] I. S. Riddervold, J. H. Bønløkke, A.-C. Olin et al., "Effects of wood smoke particles from wood-burning stoves on the respiratory health of atopic humans," Particle and Fibre Toxicology, vol. 9, no. 1, p. 12, 2012.

[5] E. Nielsen, "Health effects assessment of exposure to particles from wood smoke," Toxicology Letters, vol. 172, p. S120, 2007.

[6] A. Oikonomou and F. Bougiatioti, "Architectural structure and environmental performance of the traditional buildings in Florina, NW Greece," Building and Environment, vol. 46, no. 3, pp. 669-689, 2011.

[7] B. A. Begum, S. K. Paul, M. Dildar Hossain, S. K. Biswas, and P. K. Hopke, "Indoor air pollution from particulate matter emissions in different households in rural areas of Bangladesh," Building and Environment, vol. 44, no. 5, pp. 898-903, 2008.

[8] J. Zhang and K. R. Smith, "Household air pollution from coal and biomass fuels in China: measurements, health impacts, and interventions," Environmental Health Perspectives, vol. 115, no. 6, pp. 848-855, 2007.

[9] N. K. Bansal and India, "Characteristic parameters of a hypocaust construction," Building and Environment, vol. 34, no. 3, pp. 305-318, 1998.

[10] T. Rook, "The development and operation of Roman hypocausted baths," Journal of Archaeological Science, vol. 5, no. 3, pp. 269-282, 1978.

[11] D.-K. Kim, "The natural environment control system of Korean traditional architecture: comparison with Korean contemporary architecture," Building and Environment, vol. 41, no. 12, pp. 1905-1912, 2006.

[12] M.-S. Yeo, I.-H. Yang, and K.-W. Kim, "Historical changes and recent energy saving potential of residential heating in Korea," Energy and Buildings, vol. 35, no. 7, pp. 715-727, 2003.

[13] K.-H. Lee, D.-W. Han, and H.-J. Lim, "Passive design principles and techniques for folk houses in Cheju Island and Ullūng Island of Korea," Energy and Buildings, vol. 23, no. 3, pp. 207-216, 1996.
[14] C. Bae and C. Chun, "Research on seasonal indoor thermal environment and residents' control behavior of cooling and heating systems in Korea," Building and Environment, vol. 44, no. 11, pp. 2300-2307, 2009.

[15] G. Cao, J. Jokisalo, G. Feng, L. Duanmu, M. Vuolle, and J. Kurnitski, "Simulation of the heating performance of the Kang system in one Chinese detached house using biomass," Energy and Buildings, vol. 43, no. 1, pp. 189-199, 2011.

[16] Z. Zhuang, Y. Li, B. Chen, and J. Guo, "Chinese Kang as a domestic heating system in rural northern China-a review," Energy and Buildings, vol. 41, no. 1, pp. 111-119, 2009.

[17] W. He, Q.Y. Jiang, J. Ji, and W. Wei, "A study on thermal performance, thermal comfort in sleeping environment and solar energy contribution of solar Chinese Kang," Energy and Buildings, vol. 58, pp. 66-75, 2013.

[18] M. Yang, X. Yang, P. Wang, M. Shan, and J. Deng, "A new Chinese solar kang and its dynamic heat transfer model," Energy and Buildings, vol. 62, pp. 539-549, 2013.

[19] M. Yang, X. Yang, Z. Wang, and P. Wang, "Thermal analysis of a new solar kang system," Energy and Buildings, vol. 75, pp. 531-537, 2014.

[20] P. Wang, M. Shan, D. Xiong, and X. Yang, "A new Chinese kang with forced convection: system design and thermal performance measurements," Energy and Buildings, vol. 85, pp. 410-415, 2014.

[21] S. Hao, Y. Song, G. Zhang et al., "Design strategies on heat recovery of cooking stove in rural houses of China," in Proceedings of 31st International PLEA (Passive and Low Energy Architecture) Conference, Ahmedabad, India, December 2014.

[22] P. Wang, M. Yang, X. Yang, and M. Shan, "Thermal performance of a traditional Chinese heated wall with the inseries flow pass: experiment and modeling," Energy and Buildings, vol. 84, pp. 46-54, 2014.

[23] X. Zhang, G. Feng, and G. Feng, "Comparative analysis of heating wall with inner PCM and traditional heating wall in rural area of north China," Building Energy Environment, vol. 4, pp. 27-30, 2010, in Chinese.

[24] M. Shan, D. Li, and X. Yang, "Study on influences of combustion of fire place on indoor environment and thermal comfort in rural residences," Building Science, vol. 27, pp. 10-14, 2011, in Chinese. 


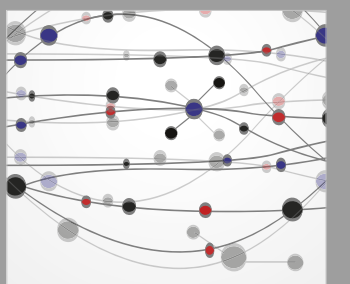

The Scientific World Journal
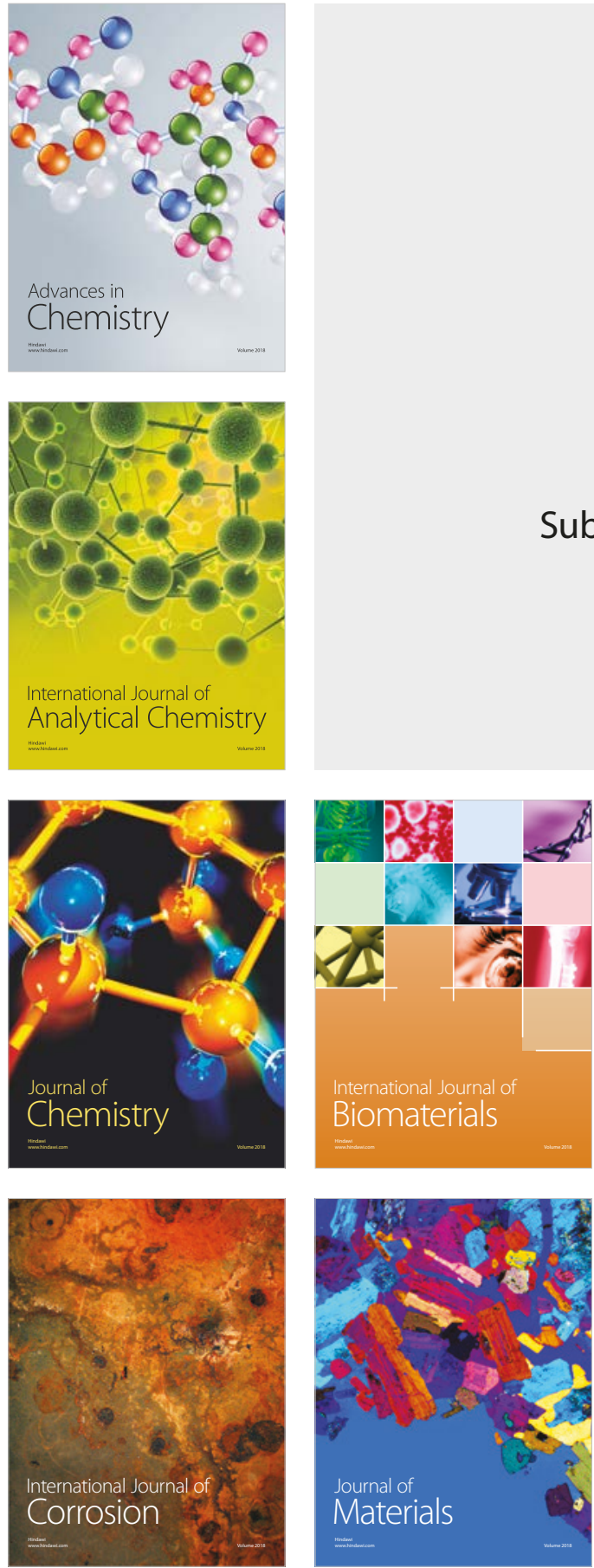

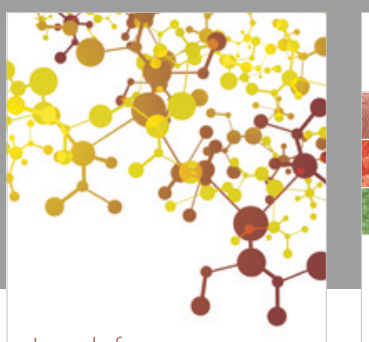

Journal of

Applied Chemistry
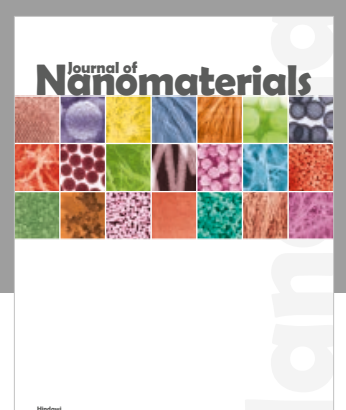

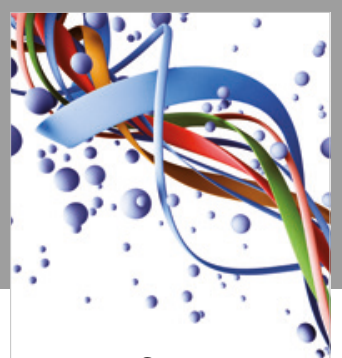

Scientifica

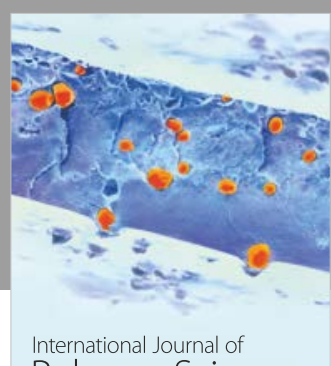

Polymer Science

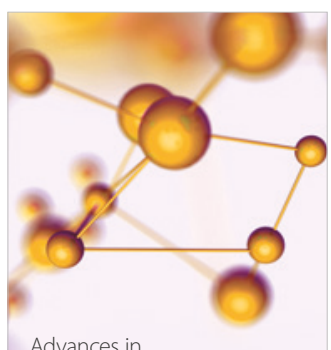

Physical Chemistry
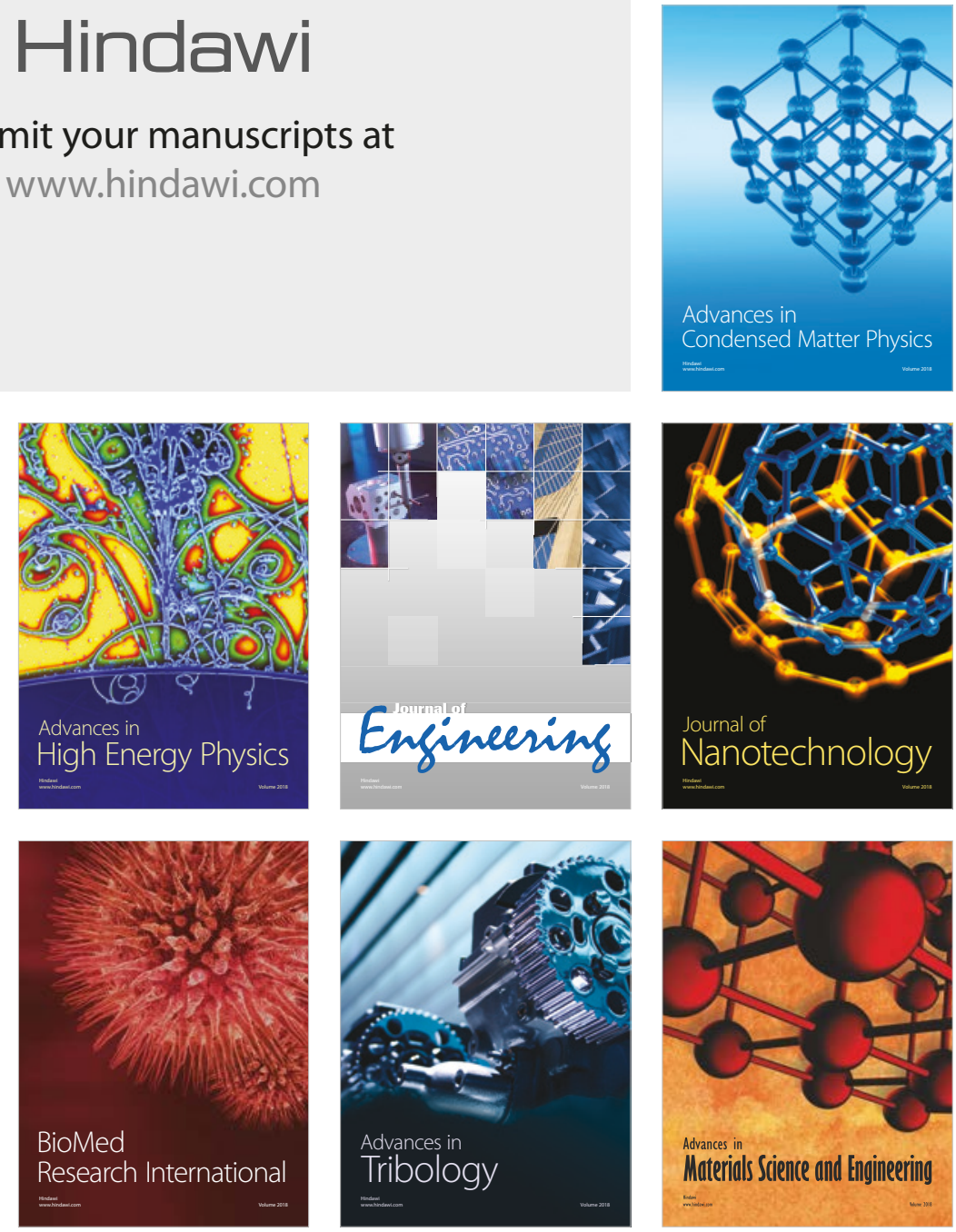